\title{
Estudios
}

\section{LA REINTERPRETACIÓN DEL DESCENSO DE CRISTO A LOS INFIERNOS EN LOS MOSAICOS LITÚRGICOS DEL CENTRO ALETTI}

Fecha de recepción: 3 de marzo de 2019

Fecha de aceptación y versión final: 11 de abril de 2019

RESUMEN: Los programas musivos de carácter litúrgico del Centro Aletti reflejan una fusión entre tradición y contemporaneidad. Entre las fuentes iconográficas procedentes de la tradición, se percibe la influencia del arte bizantino. El estudio de la historia del icono nos permite ahondar en su sentido y comprender su presencia en estos mosaicos. En el presente artículo se analiza la recuperación de la iconografía bizantina, así como de los Padres de la Iglesia, en las obras del Centro Aletti, en especial, en la reinterpretación que su director, Marko Ivan Rupnik, realiza del descenso de Cristo a los infiernos.

PALABRAS CLAVE: Centro Aletti; Marko Ivan Rupnik; arte litúrgico; icono; descenso de Cristo a los infiernos; anástasis.

* Universidad CEU San Pablo: maria.ruizloizagamartin@ceu.es; ORCID: http:// orcid.org/0000-0002-9264-5011 


\section{The Reinterpretation of the Harrowing of Hell in the Centro Aletti's Liturgical Mosaics}

ABSTRACT: The Centro Aletti's mosaic programs are of liturgical nature and reflect the merger of tradition and contemporaneity. Byzantine Art is among the iconographic sources emerging from tradition. The analysis of icon history reveals its profound meaning and the motivations for its presence in these mosaics. In this article, the reappearance of Byzantine iconography and the Church Fathers as sources of tradition in the works of the Centro Aletti is analyzed emphasizing the reinterpretation proposed by Marko Ivan Rupnik, its director, on the harrowing of hell.

KEY WORDS: Centro Aletti; Marko Ivan Rupnik; liturgical art; icon; harrowing of hell; anastasis.

\section{INTRODUCCIÓN ${ }^{1}$}

\subsection{Las obras del Centro Aletti como expresión de la teología}

Marko Ivan Rupnik (1954, Zadlog, Eslovenia) es un artista, profesor de la Pontificia Università Gregoriana y director del Centro Aletti (Roma). Este centro es, en palabras de Rupnik, «un punto de encuentro entre el este y el oeste de Europa. Encuentro entre tradición y modernidad $»^{2}$. Esta armonización entre tradición y contemporaneidad se percibe en los programas musivos de carácter litúrgico que en él se crean. Rupnik reinterpreta tipos iconográficos paleocristianos, bizantinos, románicos o góticos y, además, determinados movimientos y artistas de las vanguardias del siglo XX influyen en la configuración del lenguaje formal de estos mosaicos ${ }^{3}$. En la actualidad, sus obras se extienden por América, Oriente Medio, Australia y más de quince países de Europa.

\footnotetext{
1 Quisiera agradecer a la Dra. María Rodríguez Velasco y al Dr. José Francisco Serrano Oceja sus consejos y todo su apoyo.

2 Marko Ivan Rupnik, "El Taller del Centro Aletti", en Los colores de la luz, ed. Marko Ivan Rupnik (Burgos: Monte Carmelo, 2003), 277. Así también lo destacó san Juan Pablo II durante su inauguración. Véase: https://w2.vatican.va/content/john-paul-ii/it/ speeches/1993/december/documents/hf_jp-ii_spe_19931212_centro-aletti.html

3 Una de las influencias que recibe el Centro Aletti es Matisse. Véase: María Ruiz de Loizaga Martín, "La semplificazione delle forme. Influenza di Matisse nei mosaici di Marko Ivan Rupnik e il Centro Ezio Aletti”, Collectanea Franciscana 87 (2017): 613-634.
} 
Uno de los principios fundamentales del Centro Aletti es la vinculación entre arte y teología, como han subrayado san Juan Pablo II o Benedicto XVI. Así, en 1999, en la dedicación de la capilla Redemptoris Mater, el papa polaco afirmó que esos mosaicos se proponían «como expresión de la teología que respira con dos pulmones y puede dar nueva vitalidad a la Iglesia del tercer milenio» ${ }^{4}$. Benedicto XVI, en su visita en 2009 a San Giovanni Rotondo, comentó que esos programas musivos son una lección magistral de teología ${ }^{5}$. Por su parte, el papa Francisco también ha reconocido el valor de sus obras al encargar al Centro Aletti en diciembre de 2015 la realización del logo del Jubileo de la Misericordia.

La vinculación entre arte y teología presente en estos mosaicos se deriva de su sentido litúrgico. Rupnik señala que su arte vivifica la propia liturgia, pues su razón de ser reside «en la participación en esta totalidad de la liturgia» ${ }^{6}$. De este modo, su acción salvífica es revelada por «la arquitectura, las piedras, la madera, el vidrio, la iconografía de los santos, de los acontecimientos de la historia de la salvación ${ }^{7}$. Además, el director del Centro Aletti expone que la eclesialidad, la importancia de la tradición, el lenguaje de la propia liturgia, la inspiración del Espíritu Santo, la simplicidad, la significación de la luz y el protagonismo de la materia son los elementos principales del arte desarrollado en un espacio litúrgico ${ }^{8}$.

\subsection{Armonización de Oriente y de Occidente}

En relación con la importancia de la tradición, Rupnik recalca que para acceder al contenido de una obra de arte litúrgico hay que tener

${ }^{4}$ https://w2.vatican.va/content/john-paul-ii/es/homilies/1999/documents/hf_jpii_hom_14111999_redemptoris-mater.html

5 http:/www.iltempo.it/politica/2009/09/23/news/l-oro-degli-ex-voto-br-nellacripta-di-san-pio-707257/

6 Marko Ivan Rupnik, "Fidelidad a las intuiciones", en Los colores de la luz, ed. Marko Ivan Rupnik (Burgos: Monte Carmelo, 2003), 129.

7 Nataša Govekar, El rojo de la Plaza de Oro. Entrevista de Natasa Govekar con Marko Ivan Rupnik sobre arte, fe y evangelización (Burgos: Monte Carmelo, 2013), 65.

8 Rupnik explica estos elementos en su estudio: "Applicazione del Concilio: quale arte per la liturgia?”: Notitiae 471-472 (2005): 579-587. Véase también: María Ruiz de Loizaga Martín, "Hacia un arte litúrgico, según la concepción de Marko Ivan Rupnik. Reflexiones sobre el arte sacro", Scripta Theologica 49 (2017): 619-643. 
mucha familiaridad con la Sagrada Escritura, con los antiguos textos litúrgicos o con la patrística. Precisamente, para profundizar en la finalidad y valor de los programas musivos del Centro Aletti se hace necesario un estudio de los escritos de la tradición cristiana y de las investigaciones teológicas de los siglos XX y XXI que inspiran la obra de Rupnik. Por otro lado, la fusión de elementos procedentes de la tradición oriental y occidental está presente también en sus obras. Rupnik plantea que la existencia de estas dos tradiciones cristianas es una realidad providencial y también subraya que en ese encuentro ninguna permanece intacta. «Ambas deben pasar por una especie de muerte y resurrección». Confiesa que, por un lado, Occidente puede ayudar a Oriente a promover un diálogo entre su iconografía y las culturas actuales, de forma que esté presente una custodia y renovación constante ${ }^{9}$. La influencia occidental puede, por tanto, en muchos casos, ayudar a actualizar el lenguaje oriental. Así, por ejemplo, permite revitalizar el cierto hieratismo que en ocasiones se percibe en los iconos a partir de la fuerza del color y de juegos matéricos ${ }^{10}$. Y, por su parte, Oriente también puede fomentar en Occidente el respeto hacia la tradición. Rupnik de nuevo se refiere expresamente a este enriquecimiento recíproco entre ambas culturas:

«[...] mi investigación se ha desarrollado a través de los años sobre la relación entre Oriente y Occidente cristiano, en cuanto que en el segundo milenio Oriente, que había alcanzado una alta interpretación figurativa artística de los misterios de la fe, sufre una cierta fosilización, y Occidente, en el que prevalece un desarrollo del arte fuera de la Iglesia, liberado de la Iglesia, sufre una afirmación de la expresión del hombre» ${ }^{11}$.

En el Centro Aletti se busca, así, una síntesis del artista-iconógrafo que conduce a una unión entre la traditio y la inventio ${ }^{12}$. Estas obras de

9 Marko Ivan Rupnik, "Cómo me he acercado al mosaico de la Capilla", en $\mathrm{La}$ Capilla "Redemptoris Mater" del Papa Juan Pablo II, ed. Mariano Apa, Olivier Clément, y Crispino Valenziano, (Burgos: Monte Carmelo, 2002), 182.

10 Olivier Clément, "Un Occidente fecundado por Oriente", en La Capilla "Redemptoris Mater" del Papa Juan Pablo II, ed. Mariano Apa, Olivier Clément, y Crispino Valenziano, (Burgos: Monte Carmelo, 2002), 188.

11 Marko Ivan Rupnik, "La Capilla Papal Redemptoris Mater del Palacio Apostólico Vaticano. Pensamiento teológico, litúrgico y artístico", Patrimonio Cultural 36 (2002): 62.

12 Mariano Apa, "Redemptoris Mater. Ecclesiae Gesamtkunstwerk", en La Capilla "Redemptoris Mater" del Papa Juan Pablo II, ed. Mariano Apa, Olivier Clément, y Crispino Valenziano, (Burgos: Monte Carmelo, 2002), 259 y 263. 
arte litúrgico manifiestan de este modo que Oriente y Occidente cristiano no son y no deben ser concebidas como realidades antagónicas, sino complementarias.

Debemos precisar que no se debe identificar Oriente con la tradición y Occidente con la contemporaneidad. De hecho, recordemos que Rupnik se inspira en modelos iconográficos procedentes de la tradición occidental, como los correspondientes al arte románico o gótico, y, al mismo tiempo, está influido por autores orientales del siglo XX, como Soloviev, Ivanov o Florenski - junto a estos escritores de Oriente, también tiene muy presente las investigaciones de pensadores occidentales de los siglos XIX y XX, como Romano Guardini-.

Por tanto, Rupnik ha llegado a este intercambio de elementos de ambas procedencias a través de un largo estudio y lectura de diversos autores. Su investigación enraíza con la carta apostólica Orientale Lumen de san Juan Pablo II, en la que el pontífice señala que en Oriente y en Occidente se han seguido diversos métodos que, más que oponerse, se complementan entre sí1 ${ }^{13}$.

En este artículo ahondaremos en la influencia de los Padres de la Iglesia y de la iconografía bizantina en los programas musivos de Rupnik, en especial, en su reinterpretación de la escena del descenso de Cristo a los infiernos.

\section{LA RECUPERACIÓN DE MODELOS ICONOGRÁFICOS BIZANTI- NOS EN LOS MOSAICOS DE MARKO IVAN RUPNIK}

La influencia de la iconografía oriental en las obras del Centro Aletti está presente desde los comienzos de su actividad artística. Su director concibe el arte bizantino como una manifestación desarrollada por una cultura orgánica. Frente a la cultura crítica, caracterizada por el primado de la idea y del pensamiento, la cultura orgánica está ligada a la vida, como sucede con el arte del icono, tal y como explica Rupnik:

13 Juan Pablo II, “Carta ap. Orientale lumen (2 mayo 1995)”, 5: AAS 87 (1995), 748. Durante todo su pontificado, san Juan Pablo II subrayó esta deseada unión entre Oriente y Occidente, como en la "Encíclica Ut unum sint (25 mayo 1995)": AAS 87 (1995), 921-982. Diversos autores en la actualidad han profundizado en estas relaciones entre el cristianismo oriental y el occidental, como: Ioannis D. Zizioulas, El ser eclesial (Salamanca: Ediciones Sígueme, 2003), 39-40. 
"¿Por qué en Bizancio se sentía la necesidad de subrayar fuertemente el arte? Los cristianos se debían inculturar en un mundo ideal, intelectualmente fuerte en la lógica, en el razonamiento, siendo capaces de una enorme especulación intelectual. Y el riesgo más grave que advertían los cristianos era el ser malinterpretados como si la fe cristiana fuera una propuesta filosófica, una teoría. Pero los cristianos sabían por experiencia que la inteligencia se enraizaba en la vida y era expresión de esta vida y de esta nueva existencia recibida del Espíritu Santo en Jesucristo. Por eso trataban, en cambio, de utilizar un lenguaje que no permitiera separarse de la vida y este es el arte» ${ }^{14}$.

Es necesario que se produzca una experiencia personal entre el icono y el iconógrafo, pero también es esencial que esta continúe en el fiel, ya que una pintura se convierte en icono cuando su temática y su técnica permiten el pasaje del espectador al original, a la relación personal ${ }^{15}$.

\subsection{Sentido E Historia DeL icono}

El icono es una palabra que en griego —eikon - significa imagen, retrato. Lo cierto es que el icono es también llamado palabra-imagen, pues, «es imagen y al mismo tiempo palabra, es revelación, y al mismo tiempo anamnesis, memoria», como subrayan Rupnik y Špidlík ${ }^{16}$. La unidad palabra-imagen es, por tanto, consustancial al icono que, además, transforma en imagen la Palabra de Dios. La comunicación emerge como un elemento fundamental, pues el lenguaje iconográfico está al servicio de

${ }_{14}$ Marko Ivan Rupnik, "Lectio Academica. La belleza, lugar del conocimiento integral”, en Una belleza para el encuentro, ed. Marko Ivan Rupnik (Madrid: Universidad Francisco de Vitoria, 2013), 25.

15 Christos Yannaras, Contro la religione (Magnano: Edizioni Qiqajon, 2012), 280. Resulta interesante relacionar esta experiencia personal con el icono y la tradición oriental que, como escribe Evdokimov, «no ha distinguido jamás netamente entre mística y teología, entre la experiencia personal de los misterios divinos y el dogma confesado por la Iglesia» Paul Evdokimov, El amor loco de Dios [Madrid: Narcea, 1990], 39. Son muchos los teólogos que han subrayado la necesaria vivencia personal en la Iglesia, como Schmemann. Véase: Alexander Schmemann, Chiesa, mondo e missione (Roma: Lipa, 2014), 33.

16 Tomáš Špidlík, y Marko Ivan Rupnik, La fe según los iconos (Burgos: Monte Carmelo, 2003), 13-14. Considerado el alma del Centro Aletti, Tomáš Špidlík (19192010) es un reconocido investigador que ha estudiado principalmente la teología oriental y la sensibilidad artística de la cultura contemporánea. 
la misma, y la belleza es entendida también como comunicación. Por acción del Espíritu Santo, los medios humanos se convierten en ámbito de comunicación espiritual, de tal modo que sus formas emergen como instrumentos de comunicación de la fe. Así, «el icono es una larga cita bíblico-patrística. Es una realidad espiritual, donde espiritual es todo lo que, con la acción del Espíritu Santo, nos habla de Dios, nos lo recuerda, nos lo comunica y nos lleva a Él ${ }^{17}$, como también explican Špidlík y Rupnik. Precisamente, por su consideración como medio de transmisión de la revelación divina es por lo que «en Oriente se considera sagrado y forma parte del culto divino ${ }^{18}$.

Pero, principalmente, el icono es llamado palabra-imagen porque su valor no radica en el material con el que ha sido realizado, sino en su participación: evoca una presencia. No solo representa personas o realidades sagradas, sino que las hace presentes. La imagen lleva al prototipo $\mathrm{y}$, al mismo tiempo, es una revelación del prototipo, una presencia real del prototipo ${ }^{19}$.

Como escribe Evdokimov, todo icono es ante todo epifánico, testimonia la presencia a la que representa ${ }^{20}$. Precisamente, este es el principio a partir del cual distintos autores defenderán, desde los comienzos de la iconoclasia, en el siglo VIII, hasta la actualidad, la legitimación del uso y culto de las imágenes sagradas. Entre los iconódulos, defensores de las representaciones, destacó Juan Damasceno, cuyos tres tratados en defensa de las imágenes, además de emerger como respuesta a la iconoclasia, reflejan de forma completa y sistemática «una exposición teológica acerca de la enseñanza ortodoxa de la imagen», en palabras de Uspenski ${ }^{21}$.

Tras una gran persecución, la emperatriz Irene, en el año 780, restableció el culto a las imágenes. Siete años más tarde, tuvo lugar el segundo concilio de Nicea - VII concilio ecuménico-, en el que se ratificaron las afirmaciones de Damasceno, se pusieron los cimientos del culto a las

17 Tomáš Špidlík, y Marko Ivan Rupnik, Narrativa dell'immagine (Roma: Lipa, 1996), 18.

18 Špidlík, y Rupnik, La fe según los iconos, 24-25 y 28-29; y Tomáš Špidlík, y Marko Ivan Rupnik, El conocimiento integral. La vía del símbolo (Madrid: BAC, 2013), 103.

19 Santiago Sebastián, Mensaje simbólico del arte medieval. Arquitectura, Liturgia e Iconografía (Madrid: Encuentro, 2009), 166; y Alfonso López Quintás, "La belleza y su poder transfigurador. Mensaje del Papa a los artistas", Ars Sacra 34 (2005): 90-91.

20 Evdokimov, El amor loco, 27.

${ }^{21}$ Leonid A. Uspenski, Teología del icono (Salamanca: Ediciones Sígueme, 2013), 116. 
imágenes y, en definitiva, se definió la teología fundamental del icono. Además de Damasceno, el concilio Niceno II, citó a san Basilio e invocó también la autoridad de los «grandes doctores ortodoxos, como san Juan Crisóstomo, san Gregorio de Nisa, san Cirilo de Alejandría o san Gregorio Nacianceno», como explicó san Juan Pablo II ${ }^{22}$. Se admitió la representación de Cristo, la Virgen o los santos para ayudar a la oración y a la devoción de los fieles. Además, se estableció que, de igual modo que los textos litúrgicos o la predicación no son una simple repetición de las Sagradas Escrituras, las imágenes transmiten vitalmente aquello que contienen, lo actualizan, lo hacen presente. Por todo ello, este concilio significó la victoria del culto de las imágenes ${ }^{23}$.

No obstante, con posterioridad, en Bizancio, se produjeron nuevas persecuciones iconoclastas. En este periodo, entre los defensores del icono debemos nombrar a Teodoro el Estudita, que desarrolló la teología del culto a las imágenes e insistió en que este culto no se dirige hacia la imagen material - pues sería entonces una idolatría-, sino hacia aquel a quien la imagen representa. Fue entonces, en el año 843, cuando se reinstauró la ortodoxia de Nicea II y viene así definitivamente proclamada la victoria de la ortodoxia ${ }^{24}$.

Este evento es celebrado todos los años en la Iglesia bizantina el primer domingo de cuaresma. El triunfo de la ortodoxia no es la victoria de los iconódulos, sino la victoria de la verdadera fe en su totalidad ${ }^{25}$. Por tanto, el debate sobre las imágenes no fue —ni sigue siendo- simplemente una cuestión estética o devocional, sino que afecta a los contenidos propios de la fe, como la encarnación. De hecho, el fundamento de la defensa de una verdadera presencia en los iconos reside en el misterio de la encarnación, ya que en este misterio se celebra la victoria de la relación de Dios con el hombre por medio de lo creado ${ }^{26}$.

22 Juan Pablo II, “Carta ap. Duodecimum Saeculum (4 diciembre 1987)”, 6: AAS 80 (1988), 246.

${ }_{23}$ Maria Campatelli, Leggere la Bibbia con i Padri. Per una lettura credente delle Scritture (Roma: Lipa, 2009), 13. Por ello, el iconógrafo es comparado con el sacerdote que predica y celebra la liturgia. Véase: Špidlík, y Rupnik, El conocimiento integral, 100.

24 Juan Plazaola, Historia del arte cristiano (Madrid: BAC, 1999), 53; Mahmoud Zibawi, Iconos. Sentido e historia (Madrid: Libsa, 1999), 11; y Paul Evdokimov, El arte del icono. Teología de la belleza (Madrid: Publicaciones Claretianas, 1991), 167.

25 Maria Campatelli, "L'icona e il vedere nella liturgia bizantina", Parola, Spirito e Vita 57 (2008): 246.

${ }^{26}$ Giacomo Morandi, Bellezza, Luogo teologico di evangelizzazione (Milano: Paoline, 2009), 66; Michelina Tenace, "L'antropologia di Nicea II. Vittoria dell’Ortodossia", 
Así, la veneración del icono no es ya solo lícita, sino que emerge como el testimonio de una materia central de fe: el de la encarnación del Hijo de Dios. Uno de los argumentos que defendían los iconoclastas era la prohibición de representar lo divino en el Antiguo Testamento. Recordemos que, en el decálogo del Éxodo, Dios dice: «No te harás imagen, ni ninguna semejanza de lo que esté arriba en el cielo, ni abajo en la tierra, ni en las aguas debajo de la tierra» (Ex 20,4). Por otro lado, en el Deuteronomio, las exhortaciones de Moisés renuevan y acentúan esta prohibición (Dt 4,15-18). Pero los Padres de la Iglesia vieron que el icono estaba íntimamente relacionado con la auténtica novedad inaugurada por Cristo: el pasaje de una Palabra que es proclamada y escuchada a una Palabra que se puede ver y contemplar ${ }^{27}$. Afirmar que Dios se ha hecho hombre presupone la posibilidad de pasar de la invisibilidad a la representación, y abre una nueva relación entre lo divino y lo humano. Lo expresa de forma clara Juan Damasceno al escribir que, cuando Dios carecía de cuerpo y figura,

«[... ] no era representado de ninguna forma; pero ahora, cuando Dios ha sido visto en la carne y se ha criado junto a los hombres, represento lo que se ve de Dios. No venero la materia, sino que venero el Hacedor de la materia, al que se hizo materia por mi causa, que aceptó habitar en la materia y obró mi salvación a través de la materia (De sacris imaginibus orationes, I.16)»²8.

La justificación teológica del icono se relaciona, por tanto, con las palabras del Génesis: «el hombre fue creado a imagen y semejanza de Dios» $(\mathrm{Gn} 1,26)$ y con las reflexiones de la carta a los colosenses, en que se lee que Cristo «es la imagen del Dios invisible» (Col 1,15) y que todo cristiano debe conformarse a su imagen $(\mathrm{Rm} 8,29)$. Por todo ello, los defensores de las imágenes sostenían que la encarnación del Hijo de Dios era la que había inaugurado un modo nuevo de anuncio cuya fuerza y legitimidad se basaba en el hecho de que el Logos divino se había hecho

en $A$ due polmoni, ed. Tomáš Špidlík, (Roma: Lipa, 1999), 216; y Christoph von Schönborn, El icono de Cristo. Una introducción teológica (Madrid: Encuentro, 1999), 11. Schönborn además señala que el icono no solo se basa en la doctrina de la encarnación, sino que recuerda de forma constante la segunda venida de Cristo, por lo que se convierte en una «síntesis» del credo (ibid, 135).

27 Morandi, 117.

28 Juan de Damasco, Sobre las imágenes sagradas (Pamplona: Barañaín, 2013), 39 y 55 . 
visible. El Invisible nos ha sido comunicado a través de lo visible. La imagen de Cristo es la imagen de Dios, por ello, al contemplar el icono de Cristo observamos a la vez lo inefable y lo representado.

Por otro lado, como con Cristo llega la verdad, esta debía ser revelada no solo por la palabra, sino también por la imagen, debía ser mostrada. La verdad posee su imagen, porque la verdad no es una idea o una fórmula abstracta, sino algo concreto y con vida propia, es una persona ${ }^{29}$. Además, como la Palabra se ha hecho visible, nos encontramos ante una «teología visual», realizada mediante imágenes, colores y símbolos ${ }^{30}$. El icono invita así a conocer de modo experiencial a Dios. Como ha escrito Ratzinger, a partir de la concepción de que el rostro de Cristo es el rostro de Dios, nace el gran arte de los iconos ${ }^{31}$.

El icono no es simplemente una pintura, sino la revelación, la visibilidad, la presencia real de la persona representada, «un espacio habitado por el Señor mismo» ${ }^{32}$, en palabras de Rupnik y Špidlík. Esta imagen es la que permite el pasaje de una realidad visible a otra invisible, hecho posible, como se ha señalado, gracias a la encarnación. Por tanto, la tarea del iconógrafo consiste en conducir al fiel a contemplar lo invisible a través de lo visible, lo divino a partir de lo humano, de modo que en cada forma visible se pueda ver el misterio invisible y divino. Así, el icono es un encuentro entre el cielo y la tierra; su cometido es hacer ver a Dios y a los santos en su gloria ${ }^{33}$.

El icono nos impide pensar en la fe en términos abstractos y desencarnados al subrayar la persona concreta de $\mathrm{Cristo}^{34}$. De hecho, es el misterio de la encarnación lo que ha llevado a Rupnik a señalar la necesaria presencia de lo figurativo - junto a lo decorativo- en el arte litúrgico ${ }^{35}$.

${ }^{29}$ Uspenski, 171.

30 Campatelli, Leggere la Bibbia con in Padri, 135.

31 Joseph Ratzinger, "Chi ha visto me ha visto il Padre' (Gv 14,9). Il Volto di Cristo nella Sacra Scrittura”, en: Il volto dei volti Cristo, dir. Istituto Internazionale di Ricerca sul Volto di Cristo (Gorle: Velar, 2001), 16. Véase también: Timothy Verdon, "Arte e catechesi. Le ragioni di un metodo", en La valorizzazione dei beni culturali in senso cristiano, dir. Timothy Verdon, (Bologna: Edizione Dehoniane Bologna, 2002), 13.

32 Špidlík, y Rupnik, La fe según los iconos, 15.

33 Tomáš Špidlík, Alle fonti dell'Europa dell'Europa. In principio era l'arte (Roma: Lipa, 2006), 92.

34 Špidlík, y Rupnik, La fe según los iconos, 110.

35 En palabras de Špidlík, el "simbolismo concreto" y el "simbolismo abstracto". Véase: Tomáš Špidlík, "Los colores del invisible”, en Los colores de la luz, ed. Marko Ivan Rupnik (Burgos: Monte Carmelo, 2003), 12. 
Por otro lado, tenemos que tener en cuenta que la encarnación es también la que llevó a una valoración de la materia. Esta pasó a ser estimada con gran dignidad al ser «morada de Dios» y así convertirse en «signo y sacramento eficaz del encuentro del hombre con Dios», como escribió Ratzinger ${ }^{36}$. El propio Juan Damasceno, durante el periodo iconoclasta, en sus escritos subrayó este necesario respeto hacia la materia:

«Ultrajas la materia y dices que carece de honor. Esto también lo dicen los maniqueos. Y sin embargo la divina Escritura proclama que esta es hermosa, pues dice: "Y vio Dios todo cuanto hizo y he aquí que era muy hermoso" (Gn 1, 31). Así pues, yo también confieso que la materia es obra de Dios y que esta es hermosa (De sacris imaginibus orationes, II.13)» ${ }^{37}$.

\subsection{Aportaciones DEL Siglo XX}

Rupnik además destaca la importancia de las investigaciones realizadas por otros teólogos del siglo XX, como Vladimir Soloviev, que define como verdadera obra de arte toda representación sensible de cualquier objeto o fenómeno desde el punto de vista de su estado definitivo, por lo que el arte perfecto no tiene que encarnar el ideal absoluto solo en la imaginación, sino en la propia realidad ${ }^{38}$. Soloviev abre la puerta a la transfiguración de la materia, idea de la que también habla Sergei Bulgákov, que desarrolla su teología sobre el dogma cristológico y la sofiología, corriente teológico-mística del pensamiento ruso moderno, bajo la influencia de Soloviev y Florenski ${ }^{39}$.

Vjačeslav Ivanovič Ivanov se mostró convencido de que la propia materia siempre responde a todo con amor ${ }^{40}$. Como señala el director del Centro Aletti, este autor ruso retoma la célebre consideración de que Mi-

\footnotetext{
${ }^{36}$ https://w2.vatican.va/content/benedict-xvi/es/audiences/2009/documents/hf_ ben-xvi_aud_20090506.html

37 Juan de Damasco, 151-153.

38 Vladimir Soloviev, "Il significato universale dell'arte (1890)" en Il significato dell'amore e altri scritti, ed. Adriano Dell'Asta, (Milano: Edizioni R.C. La Casa di Matriona, 1988), 157 y 162.

39 Sergej N. Bulgakov, La sposa dell'agnello. La creazione, l'uomo, la chiesa e la storia (Bologna: EDB, 1991), 584.

40 Vjačeslav Ivanovič Ivanov, "I limiti dell'arte”, en L'estetica e la poetica in Russia, ed. Ettore Lo Gatto, (Firenze: G. C. Sansoni-Editore, 1947), 458.
} 
guel Ángel no ha esculpido el David, sino que simplemente lo ha hecho salir del mármol, hecho que permite a Ivanov subrayar que la materia tiene su propia voluntad ${ }^{41}$.

Por su parte, Pável Florenski también profundizó en la idea de la transfiguración de la materia y del $\operatorname{arte}^{42}$. Subrayó que «el amor realizado es la belleza», lo que ha llevado a Rupnik a insistir en que una obra de arte que es vivida en el amor presenta la belleza en el sentido más noble y auténtico ${ }^{43}$. El director del Centro Aletti asimismo destaca de este autor su reflexión sobre la relación de la materia y el bautismo, y el hecho de que esta quiera hacerse cuerpo:

«[...] cuando morimos en el bautismo y el Espíritu Santo se posa sobre nosotros y nos une a Cristo, nos hace pasar a la tumba de Cristo y nos hace salir fuera renacidos en Él. Este tránsito de la tumba a la resurrección, como vida en Cristo, es lo que sucede a la materia cuando el hombre la toma con amor. La materia vive entonces una especie de exodus: de la mentira a la que es impulsada, que no le hace vivir aquello para lo que fue creada, hacia su verdadero sentido» ${ }^{44}$.

Asimismo, Jean Lacroix retomó el pensamiento de que el amor necesita de la materia, y planteó que esta encuentra su sentido cuando se convierte en regalo, en don que las personas pueden ofrecer en sus encuentros. Es decir, la materia quiere convertirse en parte del amor entre las personas, como explica Rupnik. Finalmente, el director del Centro Aletti señala que Jean Corbon, sacerdote melquita que murió en Beirut en el año 2001, defendió que todo lo creado por Dios contiene un significado que revela el Espíritu Santo. El significado toma cuerpo en Cristo, pero el que lo inspira es su Espíritu ${ }^{45}$.

${ }^{41}$ Marko Ivan Rupnik, "La materia che lascia riconoscere il Signore", en Il volto dei volti Cristo, dir. Istituto Internazionale di Ricerca sul Volto di Cristo (Bergamo: Velar, 2006), 133.

${ }^{42}$ Pavel Florenskij, Lo spazio e il tempo nell'arte (Milano: Adelphi Edizioni, 1995), 61.

43 Pável Florenski, La columna y el fundamento de la verdad (Salamanca: Sígueme, 2010), 95; Marko Ivan Rupnik, "Presentazione”, en Arte e Chiesa. La volontà di un incontro della Chiesa, l'attrazione per lo scontro dell'arte contemporanea, ed. Antonio Farchione (Verona: Fede\&Cultura, 2011), 7.

${ }_{44}$ Govekar, El rojo de la Plaza de Oro, 177. La lectura de otros autores como Bulgákov o el teólogo ortodoxo Alexander Schmemann inspiran también a Rupnik a realizar este paralelismo entre la transfiguración de la materia y el bautismo.

45 Rupnik, "La materia che lascia riconoscere il Signore", 133. 
Este proceso de transfiguración de la materia y, en especial, la idea planteada por Lacroix de que la materia se convierte en donación es profundizada por Rupnik en otros estudios. Así, afirma que el mundo tiene su sentido al formar parte de la relación entre el hombre y Dios, al participar de su amor. De tal manera que, cuando alguien entrega una materia con amor, esa materia entregada lleva al rostro de la persona que la ofrece. Por tanto, cuando la materia revela su verdad se convierte en participación de la vida espiritual, unión con Cristo y comunión de la Iglesia ${ }^{46}$.

En definitiva, Rupnik defiende la importancia de recuperar en la actualidad una visión íntegra de la materia, que incluye la creación y la transfiguración. Fundamentalmente, esta transfiguración de la materia en los mosaicos del Centro Aletti se refleja en los rostros de las figuras. Si cuando se mira el rostro de una persona querida, no se piensa en que está hecho de músculos, de nervios o de piel, «sino que vence la expresión del amor», del mismo modo en los rostros de los mosaicos del Centro Aletti «ya no se debe hacer ver la materia, sino su transfiguración, es decir, la huella que es dada a la materia por el amor». Es por ello por lo que es difícil saber de qué están compuestos estos rostros. Así se potencia la verdadera voluntad de la materia: «ser cada vez más transparente» y su sentido: "ser hipostatizada, personalizada, hacerse cuerpo, rostro ${ }^{47}$.

La valoración de la materia emerge como una de las características propias del arte del Centro Aletti. Rupnik recupera el sentido que esta adquiere gracias a estos autores, al arte bizantino, así como a determinados movimientos artísticos contemporáneos. En efecto, el ennoblecimiento de la materia se ha convertido en una de las principales características del arte contemporáneo, fruto del estudio y valoración de la misma en la cultura actual a nivel integral, tal y como se aprecia en las investigaciones realizadas en otras disciplinas del saber ${ }^{48}$. Los ar-

${ }^{46}$ Marko Ivan Rupnik, "Verso un'arte sapienziale" en Lo spartiacque. Ciò che nasce e ciò che muore a Occidente, ed. Marco Guzzi, (Milano: Paoline, 2006), 170.

47 Govekar, El rojo de la Plaza de Oro, 180-181; Marko Ivan Rupnik, "El misterio intuido", en Los colores de la luz, ed. Marko Ivan Rupnik (Burgos: Monte Carmelo, 2003), 27; y Marko Ivan Rupnik, "Algunos desarrollos", en Los colores de la luz, ed. Marko Ivan Rupnik (Burgos: Monte Carmelo, 2003), 182.

${ }^{48}$ El propio Tàpies afirma que su experimentación con la materia «surge a raíz de mis reflexiones sobre la crisis del concepto de materia que, cuando empecé, era uno de los temas de actualidad en el mundo científico y filosófico» (Antoni Tàpies, "El tatuaje y el cuerpo. Entrevista con Manuel Borja-Villel. 1997”, en Antoni Tàpies. Obras, escritos y entrevistas, ed. Youssef Ishaghpour [Barcelona: Ediciones Polígrafa, 2006], 133). 
tistas no esconden ya los materiales con los que realizan sus obras, sino que los muestran con audacia al público. Lo material emerge como un lenguaje autónomo y el arte contemporáneo se caracteriza por este lenguaje de los materiales.

No obstante, la primera valoración que Rupnik hace de la materia la recibe de su padre quien, antes de empezar el trabajo en el campo, murmuraba una oración y, durante la labor, tocaba los terrones con gran cuidado. «Había algo sagrado, litúrgico en el gesto de sus manos», indica el director del Centro Aletti ${ }^{49}$.

\subsection{ICONO Y MISTAGOGÍA}

Conviene subrayar que en el Centro Aletti no se busca simplemente la decoración de espacios litúrgicos, sino que el mosaico se convierta en espacio teológico, donde se puedan percibir de forma evidente los misterios del cristianismo, como sucede en el arte bizantino. El proceso paulatino de desciframiento de la imagen y, en definitiva, el camino mistagógico que realizan tanto el artista como el fiel hasta el descubrimiento de los misterios representados en el icono también es un objetivo que se persigue con los mosaicos del Centro Aletti. González López-Corps, que subraya la necesaria interrelación entre la teología y una experiencia de fe vivida, señala que la mistagogía es «la iniciación en los misterios sacramentales» así como «la acción por la que somos conducidos por los misterios celebrados ${ }^{50}$.

$\mathrm{Al}$ igual que sucedía con los aprendices de la escuela para pintores sacros que había en el monte Athos - cuya preparación era larga: teológico-litúrgica, espiritual y técnica-, la instrucción técnica y artística del icono y de los mosaicos del Centro Aletti se complementa con el estudio de la teología y de la liturgia, unido a la práctica de la oración, pues el icono «en primer lugar no es cuestión de técnica, sino de un horizonte espiritual de vida». Son las formas materiales las que llevan a un contacto personal con el mundo divino ${ }^{51}$. De hecho, la unidad entre visible-invisible o material-inmaterial en el símbolo puede ayudar a entender la

\footnotetext{
49 Rupnik, "El misterio intuido", 38.

50 Manuel González López-Corps, "Celebramos en la liturgia de la Iglesia la fe que profesamos": Teología y Catequesis 80 (2001): 9-10.

51 Nataša Govekar, El rojo de la Plaza de Oro, 102.
} 
distancia y cercanía entre lo humano-divino ${ }^{52}$. Florenski, para ayudar a comprender mejor la realidad simbólica del icono, lo equipara a una ventana ${ }^{53}$, e Ivanov a una puerta que nos introduce en el Reino Celeste, una vía para unirnos a Cristo, el medio a partir del cual el cristiano entra en contacto con el mundo espiritual ${ }^{54}$.

Además, como los iconos no solo describen el misterio, sino que lo hacen presente, los gestos de devoción y respeto, como la inclinación o el beso, expresan la comunión entre el creyente y la realidad figurada ${ }^{55}$. Hay que señalar que el Centro Aletti ha realizado iconos musivarios a los que se dirigen específicamente estas muestras de devoción, como el de María Sedes Sapientiae, el de Lourdes o el de la Sagrada Familia.

\section{LA ESCENA DEL DESCENSO DE CRISTO A LOS INFIERNOS EN LOS PROGRAMAS DEL CENTRO ALETTI}

Entre las «doce grandes fiestas» (dodekáorton), las principales solemnidades del año litúrgico en las Iglesias orientales, se encuentra el descenso de Cristo a los infiernos. Cada festividad tiene su propia imagen, que es elaborada a partir de las Sagradas Escrituras, las obras de los $\mathrm{Pa}$ dres de la Iglesia, los escritos apócrifos y los textos de los oficios litúrgicos de las fiestas que unen todas estas fuentes y contemplan el evento ${ }^{56}$. Así, «la función de las fiestas litúrgicas es hacernos vivir en la presencia de la realidad el acontecimiento salvífico» ${ }^{57}$.

En la tradición bizantina existen dos representaciones iconográficas de la Pascua de la Resurrección: el descenso de Cristo a los infiernos y las mujeres que llevan aromas al sepulcro (miróforas). Esta última, sin embargo, ha quedado pronto ligada litúrgicamente a la rememoración de las pías mujeres, que se celebra el segundo domingo después

52 Tenace, 227.

53 Pavel Florenskij, Le porte regali. Saggio sull'icona, (Milano: Adelphi Edizioni, 2007), 60-62.

54 Vjačeslav Ivanovič Ivanov, Il grande libro delle icone russe, (Milano: Edizione Paoline, 1987), 20.

55 Campatelli, Leggere la Bibbia, 131.

56 Sania Gukova, Le feste del Signore nell'icona russa (Arezzo: C\&M Arte, 2008), 19.

57 Nataša Govekar, La Navidad en mosaicos. Con mosaicos de M.I. Rupnik y del taller del Centro Aletti (Madrid: San Pablo, 2014), 31. 
de Pascua ${ }^{58}$. Principalmente, es a partir del siglo $\mathrm{X}$ cuando el descendimiento a los infiernos se afirma como imagen de la Pascua y pasa a convertirse en un tema particularmente popular en la época bizantina medieval ${ }^{59}$.

\subsection{FuENTES DE LA ANÁSTASIS}

El origen de este episodio se encuentra en los textos apócrifos. La tercera parte del evangelio de Nicodemo se titula precisamente Descendimiento de Cristo a los infiernos y la primera parte del llamado evangelio de Bartolomé recoge asimismo este acontecimiento ${ }^{60}$. Por ello, para su representación se recurrió, principalmente, a las fuentes apócrifas (figs. 1-2).

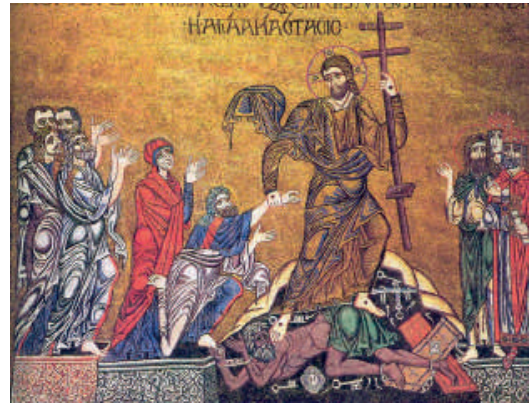

Fig. 1. Basílica de San Marcos, Venecia. Primera mitad del siglo XII

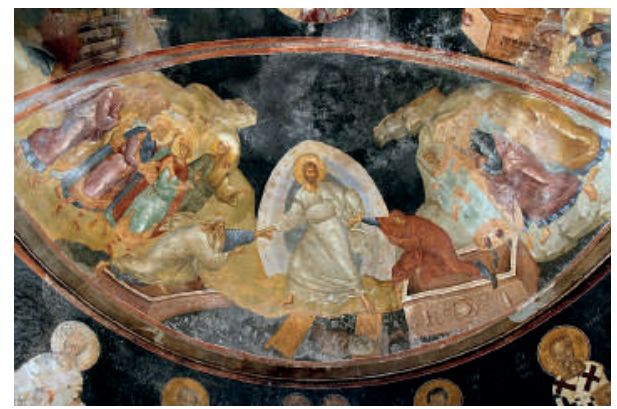

Fig. 2. San Salvador de Chora, Estambul (Turquía). Segunda década del siglo XIV

58 Gaetano Passarelli, Iconos. Festividades bizantinas (Madrid: Editorial Libsa, 2002), 11; y Evdokimov, El arte del icono, 327.

59 Gukova, 54. Hay que señalar que, aunque la formulación básica del tema corresponde a Oriente, en la Edad Media occidental también encontramos algunas variantes relevantes fruto de un desarrollo propio. Véase: Francisco de Asís García García, "La anástasis-descenso a los infiernos", Revista digital de iconografía medieval 3 (2011): 5.

${ }^{60}$ Aurelio de Santos Otero, Los evangelios apócrifos (Madrid, BAC: 2009), 236$245 ; 287-290$. 
No obstante, algunos pasajes bíblicos también fueron interpretados como una prefiguración o alusión implícita del descenso de Cristo a los infiernos. En este sentido, destacan las palabras que leemos en el evangelio de san Mateo: «porque de la misma manera que Jonás estuvo en el vientre del cetáceo tres días y tres noches, así también el Hijo del hombre estará en el seno de la tierra tres días y tres noches» (Mt 12,40) o «se abrieron los sepulcros, y muchos cuerpos de santos difuntos resucitaron» (Mt 27,52). Por otro lado, la primera epístola de Pedro habla de una predicación de Cristo entre los muertos (1Pe 3,19). Asimismo, el autor de la carta a los hebreos escribirá: «Él también participó de lo mismo, para destruir por medio de la muerte al que tenía el imperio de la muerte, esto es, al diablo, y librar a todos los que por el temor de la muerte estaban durante toda la vida sujetos a servidumbre» (Heb 2,14-15)

El descenso de Cristo a los infiernos fue incorporado como artículo de fe en el Credo de los Apóstoles y destaca especialmente en la liturgia pascual. Son muchos los autores que se refirieron a la anástasis, como Gregorio de Nisa, que escribe:

«La muerte no ocurrió por causa del nacimiento, sino al revés, que por causa de la muerte asumió Dios el nacimiento porque el Eterno no se sometió al nacimiento corporal porque tuviera necesidad de vivir, sino por llamarnos de nuevo a nosotros de la muerte a la vida. Por tanto, ya que era necesario que nuestra naturaleza regresara de la muerte toda entera, al inclinarse Él sobre nuestro cadáver para tender, por así decirlo, su mano al yacente, se acercó tanto a la muerte que entró en contacto con el estado cadavérico, y con su propio cuerpo dio a la naturaleza el principio de la resurrección, pues con su poder resucitó conjuntamente al hombre entero (Oratio catechetica magna, XXXII, 3)» ${ }^{62}$.

Por su parte, Cromacio de Aquileya señala que, con su muerte, Cristo ha destruido la muerte y ha liberado al hombre, pues la resurrección de Cristo es la llave del cielo (Sermones $1,5-6$ y 16,2) ${ }^{63}$.

${ }^{61}$ También pueden destacarse los siguientes pasajes de las Sagradas Escrituras: Sal 107, 10-16; 24, 7; Ez 28,8; y Ef 4,8-10. 132.

${ }^{62}$ Gregorio de Nisa, La gran catequesis (Madrid: Editorial Ciudad Nueva, 1994),

${ }^{63}$ Cromazio, Sermoni Liturgici (Roma: Edizione Paoline, 1982), 43 y 126. 


\subsection{La anástasis en los mosaicos del Centro Aletti}

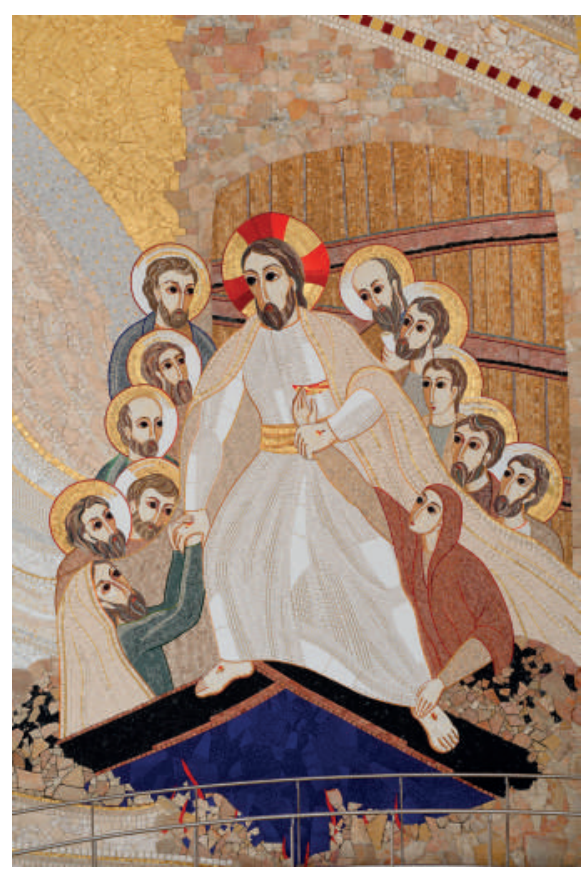

Fig. 3. Capilla en la Sacred Heart University. Fairfield, Connecticut (EE. UU.), agosto 2008. Fuente: Centro Aletti

Uno de los temas más representados en los mosaicos y esculturas del Centro Aletti es el descenso de Cristo a los infiernos o también llamado anástasis. Es el triunfo de Cristo sobre el Hades, el príncipe de las tinieblas que tiene esclavos a Adán y a su descendencia. Si las imágenes occidentales diferencian dos momentos en la muerte de Cristo, la bajada a los infiernos y su posterior resurrección; en Oriente, por el contrario, «el mismo descenso al infierno es ya la resurrección, porque la muerte es superada por medio de la muerte», como escriben Špidlík y Rupnik ${ }^{64}$. En este sentido, resulta especialmente interesante el mosaico realizado por el Centro Aletti en la capilla de la Sacred Heart University en Connecticut, donde la escena del descenso a los infiernos se fusiona con la aparición de Cristo resucitado (fig. 3).

Pero el descenso a los infiernos no representa solo la resurrección de Cristo, sino también la de toda la humanidad: tanto en los iconos como en los mosaicos del Centro Aletti, observamos a Cristo que desciende al Sheol y libera a Adán y a Eva, para llevarlos de nuevo al Padre, y con ellos, a todos los hombres. Así, san Gregorio Magno, al preguntarse si esta solemnidad es nuestra o solo de Cristo, responde que «la resurrección de nuestro Redentor fue también fiesta nuestra, porque nos devolvió la inmortalidad»(Homiliarum In Evangelia libri duo, 2, 21, 2) ${ }^{65}$.

\footnotetext{
${ }_{64}$ Špidlík, y Rupnik, La fe según los iconos, 79 y 135.

65 Gregorio Magno, Obras de San Gregorio Magno. Regla pastoral. Homilías sobre la profecía de Ezequiel. Cuarenta homilías sobre los Evangelios (Madrid: BAC, 1958), 634.
} 


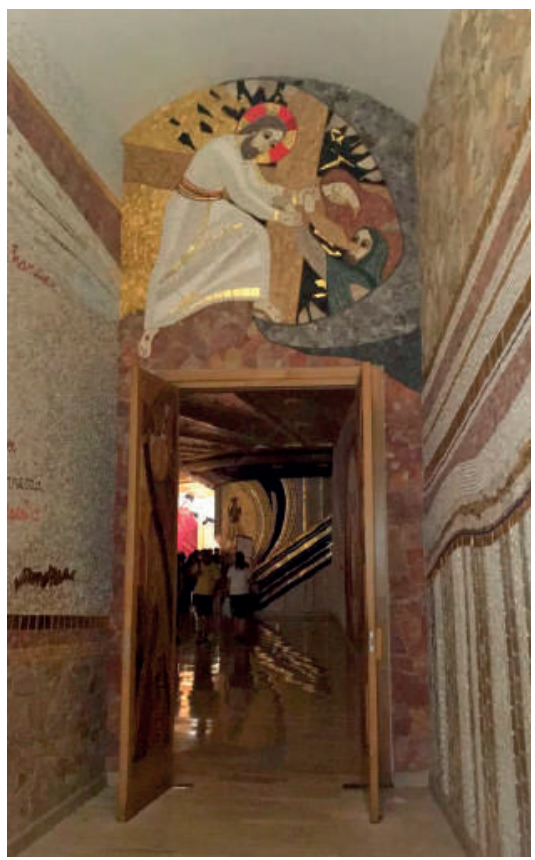

Fig. 4. Rampa de la iglesia inferior de San Pío de Pietrelcina,

San Giovanni Rotondo. Abril 2009. Fuente propia

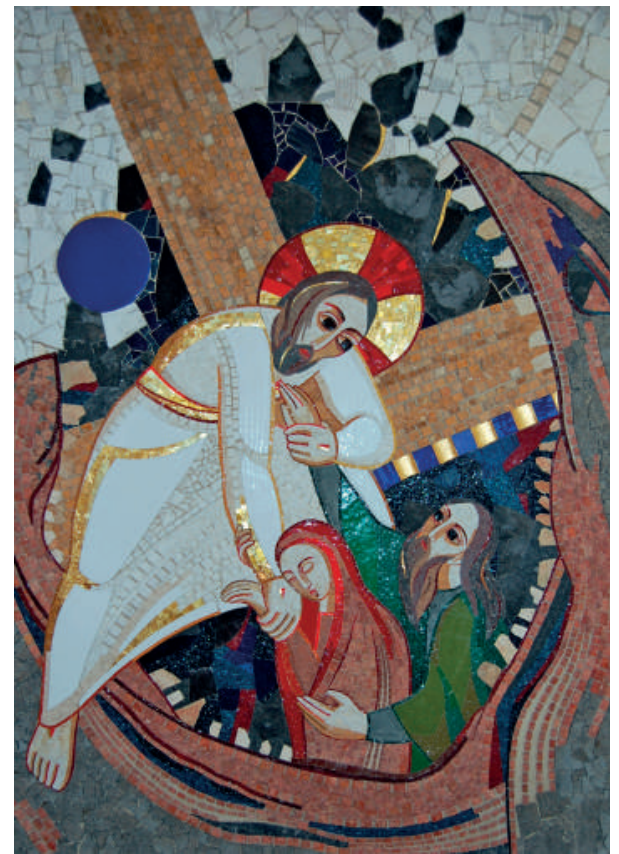

Fig. 5. Sacristía de la catedral de Santa María la Real de la Almudena. Madrid, septiembre 2005. Fuente:

Santa María la Real de la Almudena

Cristo desciende, por tanto, hasta la muerte para recuperar a la humanidad perdida. Aquel que dijo que era la puerta (Jn 10,9) abre las puertas de la muerte. En especial, resulta significativa esta concepción en la representación que el Centro Aletti realiza en San Giovanni Rotondo, pues el mosaico del descenso a los infiernos se localiza justamente sobre la puerta de ingreso (fig. 4). En muchas ocasiones, se subraya especialmente la postura pronunciada de Cristo, que se agacha hasta el fondo del Sheol para conseguir salvar a la humanidad, como observamos en Lecce o en Madrid (fig. 5).

El tema de la salvación de Adán y Eva está íntimamente relacionado con la escena del descenso de Cristo a los infiernos. Como señala Dulaey, «en fecha antigua, el recuerdo de la falta es esencialmente la pareja de 
la doctrina de la redención ${ }^{66}$. El concepto de felix culpa trajo consigo la salvación, como se indica en el pregón pascual: «Oh feliz culpa que nos ganó tan grande, tan glorioso Redentor». Este sentido salvífico, además, se refuerza por el espacio funerario en el que se encuentran muchas de las representaciones de Adán y Eva en el arte paleocristiano. Por ello, su presencia se relacionaba directamente con la salvación del difunto, cuya muerte es consecuencia de la desobediencia de Adán, pero a quien Cristo abre las puertas del paraíso ${ }^{67}$. Se traza así un paralelismo entre la expulsión del paraíso relatada en el Génesis (Gn 3,23-24) y el rescate de Adán y Eva gracias al descenso de Cristo a los infiernos.

En la escena de la anástasis, Cristo no sale de la tumba como un fugitivo, como alguien que se ha liberado de la muerte y se escapa. Tampoco aparece como un prisionero; sino como vencedor, como liberador de aquellos que se hallaban aprisionados en los infiernos ${ }^{6}$. Precisamente, la grandeza de la resurrección de Cristo reside en el hecho de que Él destruye la muerte con la muerte ${ }^{69}$. Como subraya Rupnik, Cristo no resucita solo, sino con la humanidad que ha tomado. El director del Centro Aletti especifica que, al no existir una humanidad abstracta, sino la conformada por personas concretas, en esta escena, Adán y Eva somos también nosotros ${ }^{70}$.

Cristo, tanto en las imágenes bizantinas como en las escenas del Centro Aletti, destaca por su actitud enérgica. Suele tomar a Adán por la muñeca, pues es este «el lugar donde se mide la vida», y así le devuelve la vida (fig. 6) ${ }^{71}$. Este encuentro entre Cristo y Adán encierra ya toda la historia de la salvación ${ }^{72}$. En algunos mosaicos también así es rescatada Eva; mientras que, en otras representaciones, Eva extiende sus brazos no para tomar el fruto del árbol prohibido, sino para coger las manos

${ }^{66}$ Martine Dulaey, Bosques de símbolos. La iniciación cristiana y la Biblia (siglos I-IV) (Madrid: Ediciones cristiandad, 2003), 257.

${ }^{67}$ Gaston Duchet-Suchaux, y Michel Pastoureau, La Biblia y los santos (Madrid: Alianza Editorial, 1999), 8.

68 Špidlík - Rupnik, La fe según los iconos, 79; y Passarelli, 16.

${ }_{69}$ Marko Ivan Rupnik, Il percorso di teologia e spiritualità della Cappella Redemptoris Mater (Città del Vaticano: Liberaria Editrice Vaticana, 2007), 21.

${ }^{70}$ Marko Ivan Rupnik, L'autoritratto della Chiesa. Arte, bellezza e spiritualità (Roma: EDB, 2015), 36-37.

71 Špidlík, y Rupnik, La fe según los iconos, 82.

72 Germano Marani, "La dimensione personale della discesa agli inferi", en Novità della soglia, ed. Centro Aletti (Roma: Lipa, 1995), 204. 
salvadoras de Cristo, el deseable Fruto ${ }^{73}$ (fig. 7). Resulta también significativo que, en algunas representaciones, Cristo lleva estas manos a su costado herido o a su corazón.

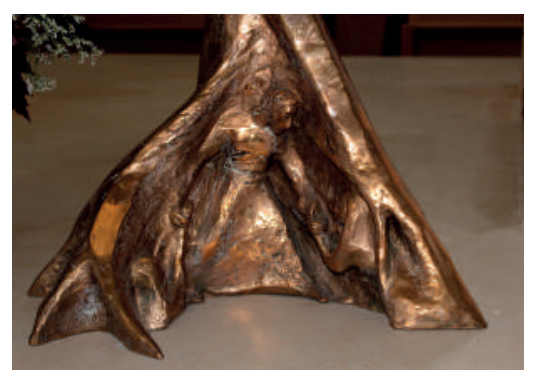

Fig. 6. Capilla del Colegio Mayor San Pablo CEU. Madrid, octubre 2009. Fuente propia

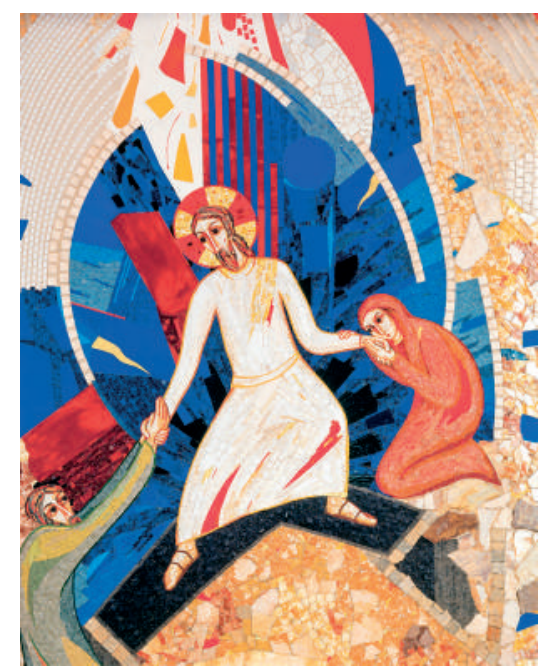

Fig. 7. Iglesia de la Santísima Trinidad. Monte Argentario, Grosseto, junio 2002. Fuente: Centro Aletti

${ }^{73}$ Morandi, 196; y Nataša Govekar, La vita in Cristo con i mosaici della cripta di San Pio (Roma: Lipa, 2014), 9. Rupnik, fiel a la esencialidad, tan solo representa a Adán y Eva, a pesar de que en algunos iconos bizantinos también encontramos las figuras de David, Salomón, Juan el Bautista, Daniel, Isaías, etc. 
El rostro de Jesús es el rostro del Padre misericordioso. En muchos mosaicos del Centro Aletti, Adán y Cristo —el viejo y nuevo Adán- presentan unos semblantes muy parecidos. Asimismo, en algunas representaciones, se subraya su cercanía, especialmente, en aquellas imágenes en las que Rupnik fusiona la iconografía bizantina de la anástasis con la del Buen Pastor. En este sentido, se puede observar una progresión: en el mosaico de la iglesia de las hermanas ursulinas en Verona, realizado en 2006, el rostro de Adán y Cristo están muy cerca, se miran mutuamente, pero aún conservan ambos los dos ojos (fig. 8). No sucede así, en cambio, en el logo de la misericordia de 2015, en el que comparten ya un mismo ojo (fig. 9).

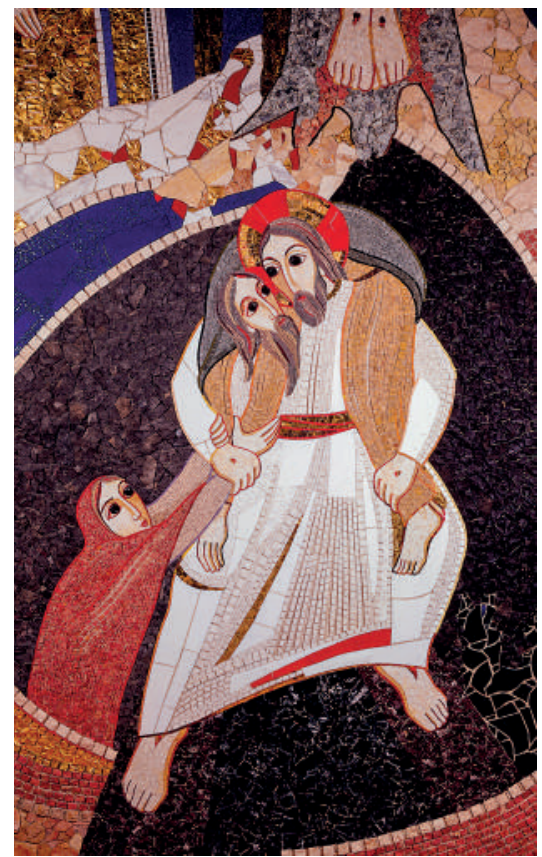

Fig. 8. Iglesia de las hermanas ursulinas Hijas de María Inmaculada. Verona, diciembre. 2006. Fuente: Centro Aletti

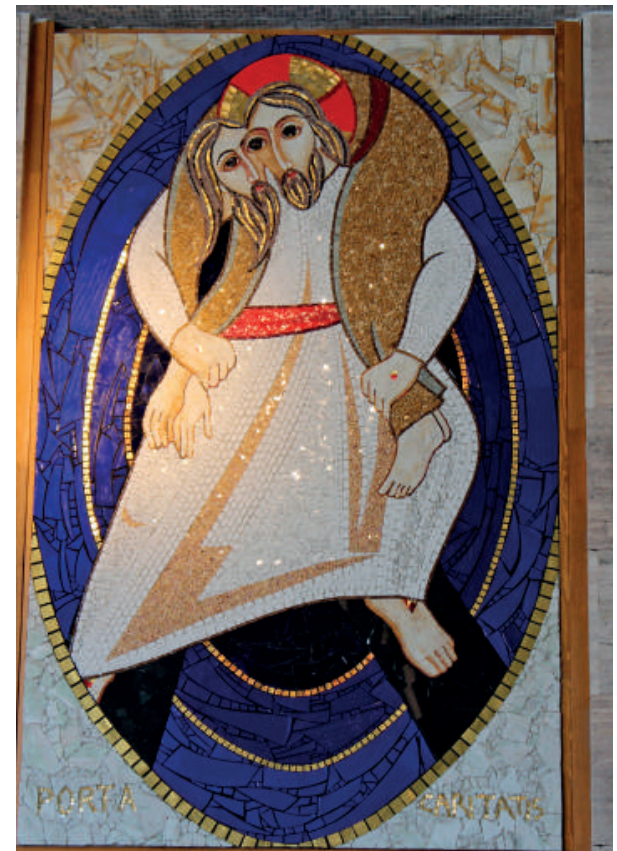

Fig. 9. Porta Caritatis. Caritas Ostello Don Luigi Di Liegro. Roma, diciembre 2015. Fuente propia 
Como sucede en tantas ocasiones en los mosaicos del Centro Aletti, este hecho no puede ser concebido como algo puramente formal, sino que esconde un significado profundo. Lo que se pretende hacer ver es que, por un lado, Dios en su Hijo aprende a mirar con el ojo de Adán, mientras que, por su parte, Adán aprende, por la misericordia, a verse a sí mismo, a los otros y al mundo con los ojos de Dios. De esta forma, el viejo Adán es redimido, porque contempla en el nuevo Adán la misericordia del Padre ${ }^{74}$.

En definitiva, la cercanía de los rostros subraya la ternura y la misericordia de Dios. El Centro Aletti ha decidido fusionar la iconografía de la anástasis con la del Buen Pastor para subrayar el hecho de que Jesús desciende a los infiernos y carga sobre sus hombros al hombre que se había extraviado. Como señala Dulaey, el vínculo entre Cristo Buen Pastor y el descenso a los infiernos se remonta a los primeros cristianos. Diversos pasajes de las Escrituras también recogen esta unión ${ }^{75}$. Así, el autor de la carta a los hebreos retoma las palabras de Isaías (Is 63,11) y escribe que Dios «resucitó de los muertos a nuestro Señor Jesucristo, el gran pastor de las ovejas» (Heb 13,20). Aunque la iconografía del Buen Pastor tuvo una especial acogida en el arte paleocristiano, entre sus representaciones, cabe destacar especialmente la que encontramos sobre la pila bautismal en Dura Europos, que resalta la recreación derivada del bautismo. En ella, junto al Buen Pastor que lleva su cordero sobre los hombros, podemos también observar a sus pies las figuras de Adán y Eva, de pie a escala reducida. El pastor que lleva la oveja puede remitir, por tanto, a una imagen del Hijo de Dios encarnado que logra la redención de la humanidad caída, gracias al descenso de Cristo a los infiernos ${ }^{76}$.

Son muchos los primeros cristianos que comentaron la unión de estos dos pasajes. Es el caso de san Ireneo, que escribe que el fruto del nacimiento de Cristo fue que descendiera a la parte más profunda de la tierra, "para buscar allí la oveja perdida, es decir, su propia obra

${ }^{74} \mathrm{https} / /$ www.centroaletti.com/opere/porta-della-carita-alla-caritas-roma-2015/ Véase también: José Manuel Carrión, “El logo del Año de la Misericordia. Una aproximación al arte litúrgico de Marko Ivan Rupnik”, Scripta Theologica 48 (2016): 731-751.

75 Dulaey, 87-89.

${ }_{76}$ Mahmoud Zibawi, "Los orígenes del arte cristiano, siglo III", en El arte paleocristiano. Visión y espacio de los orígenes a Bizancio, ed. Maria Antonietta Crippa, et al. (Madrid: Lunwerg, 1998), 71; y Dulaey, Bosques de símbolos, 87-90 y 311. 
modelada por Él, y que subiera después a lo más alto del cielo para ofrecer y entregar a su Padre al hombre que había sido recobrado, efectuando en sí las primicias de la resurrección del hombre» (Adversus haereses, III, 19, 3) ${ }^{77}$. También podríamos señalar las reflexiones de Nicolás Cabasilas en las que escribe:

«Él mismo se abajó a la tierra y de nuevo encontró su imagen. Vino a los lugares donde erraba la oveja y la tomó en sus hombros, poniendo fin a su errante vagar, no se la llevó del mundo, mas conservándola en la tierra la dejó hecha celestial. Nos otorgó la Vida del cielo, no elevándonos al cielo, sino abajando los cielos y descendiendo hasta nosotros, como lo dice el Profeta: "Abajó los cielos y descendió" ${ }^{78}$.

Por otro lado, Cristo en los mosaicos que de este pasaje realiza el Centro Aletti va vestido siempre de blanco, para recordar que «la luz luce en las tinieblas, y las tinieblas no la sofocaron» (Jn 1,5). Jesús entra en la oscuridad de la muerte y da "luz a los que habitan en tinieblas y en sombra de muerte» (Lc 1,79). De este modo, estas imágenes nos recuerdan también las palabras de Gregorio Magno, que escribe que «se mostró revestido de blanca vestidura, porque anunció los gozos de nuestra festividad; así que la blanca vestidura es nuncio del esplendor de nuestra solemnidad» (Homiliarum In Evangelia libri duo, $2,21,2)^{79}$.

Además, uno de los elementos más significativos tanto de las obras bizantinas como de los mosaicos del Centro Aletti es la cruz, que emerge como el símbolo del triunfo sobre la muerte y como símbolo de la

77 Ireneo, Contra las herejías. Libro III (Sevilla: Apostolado mariano, 1994), 115. Véase también su Epideixis, 33 (Ireneo, Demostración de la predicación apostólica, ed. E. Romero Pose (FuP 2; Madrid: Ciudad Nueva, 1992), 124-126. Asimismo, san Ambrosio se referirá a estos dos pasajes. Véase: Apologia Altera Prophetae David, 2122 (Ambroise, Apologie de David, ed. P. Hadot (SCh 293 ; Paris: Les Éditions du Cerf, 1977), 97-99.

78 Nicolás Cabasilas, La vida en Cristo (Madrid: Ediciones Rialp, 1999), 29-30 y 50. Rupnik también tiene en cuenta las palabras que escribió Benedicto XVI: «el verdadero pastor es Aquel que conoce también el camino que pasa por el valle de la muerte; [...] Él mismo ha recorrido este camino, ha bajado al reino de la muerte, la ha vencido, y ha vuelto para acompañarnos ahora y darnos la certeza de que, con Él, se encuentra siempre un paso abierto" ("Carta encíclica Spe Salvi (30 noviembre 2007)": 6, AAS 99 (2007), 991).

79 Gregorio Magno, 634. 
redención. Su uso se generaliza en las imágenes de la anástasis desde el siglo XI. De ella ya se habla en el evangelio apócrifo de Nicodemo, en el que podemos leer: "puso el Señor su cruz en medio del infierno, que es señal de victoria y permanecerá por toda la eternidad» $(3,10)^{80}$. Así, la cruz, con la que Cristo fue sacrificado, es también la que le ha permitido descender al Sheol. Por tanto, este elemento es concebido como el puente que permite a Cristo descender a los infiernos y, por ello, Rupnik la presenta como «el verdadero camino a la vida» ${ }^{81}$. Ciertamente, en los mosaicos del Centro Aletti, como en muchas representaciones bizantinas, suele introducirse en la boca del Sheol para impedir que pueda cerrarse, y permitir así la liberación de los justos. Ahora sí se puede cantar: «¿Dónde está, muerte, tu victoria? ¿dónde, muerte, tu aguijón?» (1Cor 15,55).

Los infiernos son representados en las imágenes bizantinas y en algunos mosaicos del Centro Aletti como si se trataran de un pozo o un foso. Su oscuridad recuerda a la cueva oscura de Belén propia de los iconos de la Natividad o a las aguas del Jordán en los iconos del bautismo ${ }^{82}$. Rupnik también los representa con la figura de un monstruo (figs. 4, 5, 10) ${ }^{83}$. En otras ocasiones, como en la capilla Redemptoris Mater o en el logo de la misericordia (fig. 9), Cristo aparece en una mandorla. De este modo, se subraya la noche de la muerte, pero también se refleja el misterio impenetrable del amor de Dios. Como explica Rupnik, el marco en forma de almendra en el que aparece Cristo en algunas imágenes bizantinas, «emana luz en su exterior mientras que su interior permanece impenetrable para quien no tiene mente y corazón puros» ${ }^{84}$.

80 Santos Otero, 244.

81 Rupnik, "Algunos desarrollos", 208. También la cruz puede asemejarse a una llave que abre las puertas de la muerte.

82 En algunos iconos bizantinos, una figura humana encadenada a una superficie negra personifica a Satanás vencido y un conjunto de clavos, cadenas y llaves rotas representan los restos de las puertas del infierno derribadas (Zibawi, Iconos, 98).

${ }^{83}$ La explicación de este monstruo podría relacionarse con la boca de Leviatán como imagen de los infiernos que contemplamos especialmente en representaciones bajomedievales. García García, "La anástasis-descenso a los infiernos", 7.

${ }^{84}$ Marko Ivan Rupnik, "La iconografía trinitaria de la sala capitular" en La Catedral de la Almudena. Mosaicos de la Sacristía Mayor y Sala Capitular, ed. Marko Ivan Rupnik, y Pablo Cervera Barranco, (Burgos: Monte Carmelo, 2008), 78. 


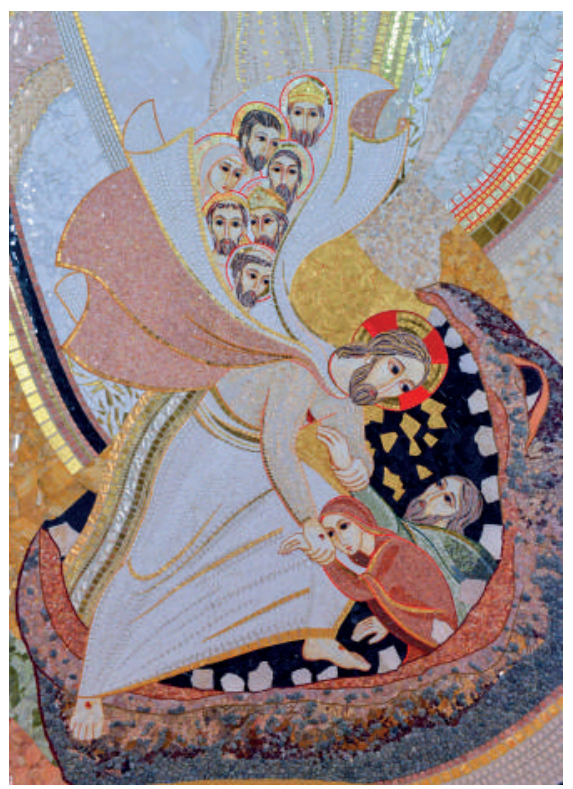

Fig. 10. Baptisterio de la iglesia de San Agustín y Santa Mónica. Casciago, marzo 2015. Fuente: Centro Aletti

Por último, es importante tener en cuenta que la escena del descenso de Cristo a los infiernos se puede vincular con el sacramento del bautismo. Ya san Pablo había escrito que nuestra salvación comienza en el bautismo, que es el paso de la cruz y la muerte a la resurrección (Rom 6,3-11). De hecho, debemos recordar que en la misma noche de la Pascua era administrado ordinariamente este sacramento. El Centro Aletti tiene presente estas reflexiones, ya que, como hemos señalado, las aguas oscuras del Jordán en sus mosaicos remiten al espacio que rodea a Cristo en su descenso a los infiernos. Estas representaciones también podrían relacionarse con las palabras que en el siglo XX utiliza Evdokimov para referirse al Jordán: «tumba líquida, abismo de la materia acuática que esconde los poderes del mal ${ }^{85}$. La vinculación entre el bautismo y el descenso de Cristo a los infiernos resulta especialmente interesante al abordar el mosaico del Centro Aletti que encontramos en Casciago, al estar situado precisamente en el baptisterio (fig. 10).

\footnotetext{
85 Evdokimov, El arte del icono, 322.
} 


\section{CONCLUSIÓN}

Los programas musivarios del Centro Aletti emergen como un ejemplo actual de arte litúrgico. Su director, Marko Ivan Rupnik, no trata simplemente de mostrar temas religiosos, de ilustrar episodios sagrados o de decorar un espacio, sino de lograr que el arte revele y haga presente el misterio de la fe, incluso cuando la liturgia no se celebra.

Para crear un arte verdaderamente litúrgico, Rupnik plantea la necesidad de un equilibrio entre figuración y abstracción. Así, si el dinamismo de los fondos de los mosaicos del Centro Aletti permite acoger mejor el contenido proporcionado por las figuras, los rostros constituyen un elemento esencial. Rupnik deduce que, si la fe cristiana se basa en la encarnación, el arte cristiano se debe referir a la persona de Cristo ${ }^{86}$. De esta forma, estos rostros musivos no son solo fruto de la técnica o del talento del artista, sino resultado de una experiencia personal entre este y la figura representada. Además, dicho diálogo debe continuar en el fiel que la contempla.

Por otro lado, para configurar las fórmulas de representación de los mosaicos del Centro Aletti, Rupnik se inspira en determinadas fuentes literarias vinculadas a la teología. Así, promueve la familiarización con las Sagradas Escrituras, los escritos de los Padres de la Iglesia y la doctrina transmitida por la tradición. Al mismo tiempo, fomenta la lectura de teólogos contemporáneos, cuyas reflexiones nos permiten interpretar el carácter conceptual de las propuestas formales de dichos mosaicos.

Precisamente, para crear el lenguaje formal de sus programas musivos, Rupnik se inspira en artistas y movimientos del siglo XX. Es consciente de que sus obras se dirigen al hombre del siglo XXI y, por ello, considera que la fe debe ser expresada en el lenguaje propio de cada época ${ }^{87}$. Asimismo, con el objeto de lograr una mayor comunicación, tiene presente las obras creadas en las grandes épocas del arte oriental

\footnotetext{
${ }^{86}$ Govekar, El rojo de la Plaza de Oro, 56.

87 Son diversas las investigaciones que profundizan en esta idea. Podemos destacar: La Capilla "Redemptoris Mater" del Papa Juan Pablo II, ed. Mariano Apa, Olivier Clément, y Crispino Valenziano, (Burgos: Monte Carmelo, 2002), Tradición y Modernidad en la obra de Marko Iván Rupnik, coord. María Rodríguez Velasco, (Madrid: CEU Ediciones, 2013) o María Rodríguez Velasco, "Reinterpretación de la concepción artística y los tipos iconográficos paleocristianos, bizantinos y románicos en los mosaicos del Centro Aletti (Roma): El programa iconográfico de la capilla del Colegio Mayor San Pablo (Madrid, octubre de 2009)", Hispania Sacra 140 (2017): 755-764.
} 
y occidental. Estas grandes épocas, como la propia del arte bizantino, se corresponden con las llamadas culturas orgánicas, en las que destacan la mentalidad simbólica y la comunión. La concepción simbólica de las obras del Centro Aletti invita a descubrir en ellas una realidad más profunda; en definitiva, manifiestan, revelan y comunican el misterio de la fe.

Concretamente, el camino mistagógico que realizan tanto el artista como el fiel hasta el descubrimiento de los misterios representados en el icono es un objetivo que también se persigue en las representaciones musivas del Centro Aletti. Además, se pueden trazar paralelismos entre los iconos de las doce grandes fiestas del año litúrgico en las Iglesias orientales con algunas representaciones musivarias del Centro Aletti. Es el caso del descenso de Cristo a los infiernos. Para su configuración, Rupnik toma como fuente de inspiración las Sagradas Escrituras y los textos patrísticos. Son muchos los autores de los primeros siglos del cristianismo que profundizaron en su significación, como san Ireneo, san Gregorio de Nisa, san Cromacio de Aquileya o san Gregorio Magno.

En sus representaciones de la anástasis, Rupnik quiere subrayar el triunfo de Cristo sobre el Hades y la misericordia de Dios. Además, en algunos programas musivos del Centro Aletti la fusión de esta iconografía con la del Buen Pastor o la del bautismo de Cristo refuerza su sentido salvífico.

\section{REFERENCIAS}

Ambroise. Apologie de David, ed. P. Hadot, SCh 293. Paris: Les Éditions du Cerf, 1977.

Apa, Mariano. "Redemptoris Mater. Ecclesiae Gesamtkunstwerk". En La Capilla «Redemptoris Mater» del Papa Juan Pablo II, editado por Mariano Apa, Olivier Clément, y Crispino Valenziano, 241-267. Burgos: Monte Carmelo, 2002.

Benedicto XVI. "Carta encíclica Spe Salvi (30 noviembre 2007)". AAS 99 (2007).

—. "Audiencia general". 25 febrero 2019. https://w2.vatican.va/content/benedict-xvi/es/audiences/2009/documents/hf_ben-xvi_aud_20090506. html (6 mayo 2009)

Bulgakov, Sergej N. La sposa dell'agnello. La creazione, l'uomo, la chiesa e la storia. Bologna: EDB, 1991. 
Campatelli, Maria. "L'icona e il vedere nella liturgia bizantina". Parola, Spirito e Vita 57 (2008): 235-247.

- Leggere la Bibbia con i Padri. Per una lettura credente delle Scritture. Roma: Lipa, 2009.

Carrión, José Manuel. "El logo del Año de la Misericordia. Una aproximación al arte litúrgico de Marko Ivan Rupnik”. Scripta Theologica 48 (2016): 731-751. DOI: https://doi.org/10.15581/006.48.3.731-751

Centro Aletti, "Porta della Carità alla Caritas di Roma (2015)". 25 febrero 2019. https://www.centroaletti.com/opere/porta-della-caritaalla-caritas-roma-2015/

Clément, Olivier. "Un Occidente fecundado por Oriente". En La Capilla "Redemptoris Mater" del Papa Juan Pablo II, editado por Mariano Apa, Olivier Clément, y Crispino Valenziano, 185-194. Burgos: Monte Carmelo, 2002.

Cromazio. Sermoni Liturgici. Roma: Edizione Paoline, 1982.

Duchet-Suchaux, Gaston, y Michel Pastoureau. La Biblia y los santos. Madrid: Alianza Editorial, 1999.

Dulaey, Martine. Bosques de símbolos. La iniciación cristiana y la Biblia (siglos I-IV). Madrid: Ediciones cristiandad, 2003.

Evdokimov, Paul. El amor loco de Dios. Madrid: Narcea, 1990.

- El arte del icono. Teología de la belleza. Madrid: Publicaciones Claretianas, 1991.

Florenskij, Pavel. Lo spazio e il tempo nell'arte. Milano: Adelphi Edizioni, 1995.

- Le porte regali. Saggio sull'icona. Milano: Adelphi Edizioni, 2007.

- La columna y el fundamento de la verdad. Salamanca: Sígueme, 2010.

García García, Francisco de Asís. "La anástasis-descenso a los infiernos". Revista digital de iconografía medieval 3 (2011): 1-17.

González López-Corps, Manuel. "Celebramos en la liturgia de la Iglesia la fe que profesamos”. Teología y Catequesis 80 (2001): 9-20.

Govekar, Nataša. El rojo de la Plaza de Oro. Entrevista de Natasa Govekar con Marko Ivan Rupnik sobre arte, fe y evangelización. Burgos: Monte Carmelo, 2013.

- La Navidad en mosaicos. Con mosaicos de M. I. Rupnik y del taller del Centro Aletti. Madrid: San Pablo, 2014.

- La vita in Cristo con i mosaici della cripta di San Pio. Roma: Lipa, 2014. 
Gregorio de Nisa. La gran catequesis. Madrid: Editorial Ciudad Nueva, 1994.

Gregorio Magno. Obras de San Gregorio Magno. Regla pastoral. Homilías sobre la profecía de Ezequiel. Cuarenta homilías sobre los Evangelios. Madrid: BAC, 1958.

Gukova, Sania. Le feste del Signore nell'icona russa. Arezzo: C\&M Arte, 2008.

Ireneo. Demostración de la predicación apostólica, ed. E. Romero Pose, FuP 2. Madrid: Ciudad Nueva, 1992.

-. Contra las herejías. Libro III. Sevilla: Apostolado mariano, 1994.

Ivanov, Vjačeslav Ivanovič. "I limiti dell'arte". En L'estetica e la poetica in Russia, editado por Ettore Lo Gatto, 450-470. Firenze: G. C. Sansoni-Editore, 1947.

—. Il grande libro delle icone russe. Milano: Edizione Paoline, 1987.

Juan de Damasco. Sobre las imágenes sagradas. Pamplona: Barañaín, 2013.

Juan Pablo II. "Carta apostólica Duodecimum Saeculum, (4 diciembre 1987)”. AAS 80 (1988).

—. "Carta apostólica Orientale Lumen, (2 mayo 1995)". AAS 87 (1995).

—. "Encíclica Ut unum sint (25 mayo 1995)". AAS 87 (1995).

- "Visita al Pontificio Istituto Orientale". 25 febrero 2018. https://w2. vatican.va/content/john-paul-ii/it/speeches/1993/december/documents/hf_jp-ii_spe_19931212_centro-aletti.html (12 diciembre 1993)

—. "Dedicación de la Capilla Redemptoris Mater". 25 febrero 2018. https://w2.vatican.va/content/john-paul-ii/es/homilies/1999/documents/hf_jp-ii_hom_14111999_redemptoris-mater.html (14 noviembre 1999)

López Quintás, Alfonso. "La belleza y su poder transfigurador. Mensaje del Papa a los artistas". Ars Sacra 34 (2005): 88-93.

Marani, Germano. "La dimensione personale della discesa agli inferi”. En Novità della soglia, editado por Centro Aletti, 201-226. Roma: Lipa, 1995, 204.

Morandi, Giacomo. Bellezza, Luogo teologico di evangelizzazione. Milano: Paoline, 2009.

Nicolás Cabasilas. La vida en Cristo. Madrid: Ediciones Rialp, 1999.

Passarelli, Gaetano. Iconos. Festividades bizantinas. Madrid: Editorial Libsa, 2002.

Plazaola, Juan. Historia del arte cristiano. Madrid: BAC, 1999. 
Ratzinger, Joseph. "«Chi ha visto me ha visto il Padre» (Gv 14,9). Il Volto di Cristo nella Sacra Scrittura". En Il volto dei volti Cristo, dirigido por Istituto Internazionale di Ricerca sul Volto di Cristo, 11-18. Gorle: Velar, 2001.

Rodríguez Velasco, María. Tradición y Modernidad en la obra de Marko Iván Rupnik. Madrid: CEU Ediciones, 2013.

—. "Reinterpretación de la concepción artística y los tipos iconográficos paleocristianos, bizantinos y románicos en los mosaicos del Centro Aletti (Roma): El programa iconográfico de la capilla del Colegio Mayor San Pablo (Madrid, octubre de 2009)". Hispania Sacra 140 (2017): 755-764. DOI: https://doi.org/10.3989/hs.2017.047

Ruiz de Loizaga Martín, María. "Hacia un arte litúrgico, según la concepción de Marko Ivan Rupnik. Reflexiones sobre el arte sacro". Scripta Theologica 49 (2017): 619-643. DOI: https://doi. org/10.15581/006.49.3.619-643

—. "La semplificazione delle forme. Influenza di Matisse nei mosaici di Marko Ivan Rupnik e il Centro Ezio Aletti". Collectanea Franciscana 87 (2017): 613-634.

Rupnik, Marko Ivan. "Cómo me he acercado al mosaico de la Capilla". En La Capilla "Redemptoris Mater" del Papa Juan Pablo II, editado por Mariano Apa, Olivier Clément, y Crispino Valenziano, 179-184. Burgos: Monte Carmelo, 2002.

- . "La Capilla Papal Redemptoris Mater del Palacio Apostólico Vaticano. Pensamiento teológico, litúrgico y artístico". Patrimonio Cultural 36 (2002): 61-72.

-. "Algunos desarrollos". En Los colores de la luz, editado por Marko Ivan Rupnik, 178-249. Burgos: Monte Carmelo, 2003.

-. "El misterio intuido". En Los colores de la luz, editado por Marko Ivan Rupnik, 16-71. Burgos: Monte Carmelo, 2003.

-. "El Taller del Centro Aletti". En Los colores de la luz, editado por Marko Ivan Rupnik, 276-282. Burgos: Monte Carmelo, 2003.

- . "Fidelidad a las intuiciones". En Los colores de la luz, editado por Marko Ivan Rupnik, 72-151. Burgos: Monte Carmelo, 2003.

- "Applicazione del Concilio: quale arte per la liturgia?". Notitiae 471472 (2005): 579-587.

-. "La materia che lascia riconoscere il Signore". En Il volto dei volti Cristo, editado por Istituto Internazionale di Ricerca sul Volto di Cristo, 133-136. Bergamo: Velar, 2006. 
- . "Verso un'arte sapienziale". En Lo spartiacque. Ciò che nasce e ciò che muore a Occidente, editado por Marco Guzzi, 161-176. Milano: Paoline, 2006.

-. Il percorso di teologia e spiritualità della Cappella Redemptoris Mater. Città del Vaticano: Liberaria Editrice Vaticana, 2007.

- . "La iconografía trinitaria de la sala capitular". En La Catedral de la Almudena. Mosaicos de la Sacristía Mayor y Sala Capitular, editado por Marko Ivan Rupnik, y Pablo Cervera Barranco, 77-149. Burgos: Monte Carmelo, 2008.

-. "Presentazione". En Arte e Chiesa. La volontà di un incontro della Chiesa, l'attrazione per lo scontro dell'arte contemporanea, editado por Antonio Farchione, 5-11. Verona: Fede\&Cultura, 2011.

-. "Lectio Academica. La belleza, lugar del conocimiento integral". En Una belleza para el encuentro, editado por Marko Ivan Rupnik, 13-27. Madrid: Universidad Francisco de Vitoria, 2013.

-. L'autoritratto della Chiesa. Arte, bellezza e spiritualità. Roma: EDB, 2015. Santos Otero, Aurelio de. Los evangelios apócrifos. Madrid: BAC, 2009. Schmemann, Alexander. Chiesa, mondo e missione. Roma: Lipa, 2014. Schönborn, Christoph von. El icono de Cristo. Una introducción teológica. Madrid: Encuentro, 1999.

Sebastián, Santiago. Mensaje simbólico del arte medieval. Arquitectura, Liturgia e Iconografía. Madrid: Encuentro, 2009.

Soloviev, Vladimir. "Il significato universale dell'arte (1890)". En Il significato dell'amore e altri scritti, editado por Adriano Dell'Asta, 149-162. Milano: Edizioni R.C. La Casa di Matriona, 1988.

Špidlík, Tomáš. "Los colores del invisible". En Los colores de la luz, editado por Marko Ivan Rupnik, 11-12. Burgos: Monte Carmelo, 2003.

- Alle fonti dell'Europa dell'Europa. In principio era l'arte. Roma: Lipa, 2006.

Špidlík, Tomáš, y Marko Ivan Rupnik. Narrativa dell'immagine. Roma: Lipa, 1996.

—. La fe según los iconos. Burgos: Monte Carmelo, 2003.

-. El conocimiento integral. La vía del símbolo. Madrid: BAC, 2013.

Tàpies, Antoni. "El tatuaje y el cuerpo. Entrevista con Manuel Borja-Villel. 1997". En Antoni Tàpies. Obras, escritos y entrevistas, editado por Youssef Ishaghpour, 133-146. Barcelona: Ediciones Polígrafa, 2006.

Tenace, Michelina. "Lantropologia di Nicea II. Vittoria dell'Ortodossia". En A due polmoni, editado por Tomáš Špidlík, 213-235. Roma: Lipa, 1999. 
Uspenski, Leonid A. Teología del icono. Salamanca: Ediciones Sígueme, 2013.

Verdon, Timothy. "Arte e catechesi. Le ragioni di un metodo". En La valorizzazione dei beni culturali in senso cristiano, dirigido por Timothy Verdon, 11-23. Bologna: Edizione Dehoniane Bologna, 2002.

Yannaras, Christos. Contro la religione. Magnano: Edizioni Qiqajon, 2012.

Zibawi, Mahmoud. "Los orígenes del arte cristiano, siglo III". En El arte paleocristiano. Visión y espacio de los orígenes a Bizancio, editado por Maria Antonietta Crippa et al., 69-108. Madrid: Lunwerg, 1998.

-. Iconos. Sentido e historia. Madrid: Libsa, 1999.

Zizioulas, Ioannis D. El ser eclesial. Salamanca: Ediciones Sígueme, 2003. 